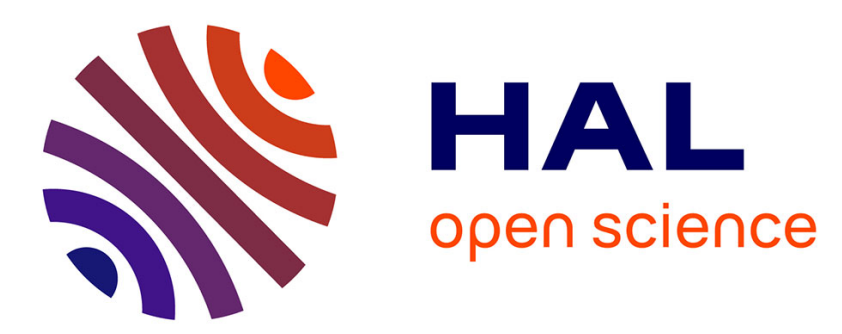

\title{
Oxidation of petrogenic organic carbon in the Amazon floodplain as a source of atmospheric CO2
}

Julien Bouchez, Olivier Beyssac, Valier Galy, Jérôme Gaillardet, Christian France-Lanord, Laurence Maurice, Patricia Moreira-Turcq

\section{- To cite this version:}

Julien Bouchez, Olivier Beyssac, Valier Galy, Jérôme Gaillardet, Christian France-Lanord, et al.. Oxidation of petrogenic organic carbon in the Amazon floodplain as a source of atmospheric $\mathrm{CO} 2$. Geology, 2010, 38 (3), pp.255-258. 10.1130/G30608 . ird-00588739

\section{HAL Id: ird-00588739 \\ https://hal.ird.fr/ird-00588739}

Submitted on 26 Apr 2011

HAL is a multi-disciplinary open access archive for the deposit and dissemination of scientific research documents, whether they are published or not. The documents may come from teaching and research institutions in France or abroad, or from public or private research centers.
L'archive ouverte pluridisciplinaire HAL, est destinée au dépôt et à la diffusion de documents scientifiques de niveau recherche, publiés ou non, émanant des établissements d'enseignement et de recherche français ou étrangers, des laboratoires publics ou privés. 
Publisher: GSA

Journal: GEOL: Geology

Article ID: G30608

\section{Oxidation of petrogenic organic carbon in the Amazon}

\section{2 floodplain as a source of atmospheric $\mathrm{CO}_{2}$}

3 Julien Bouchez $^{1,2}$, Olivier Beyssac ${ }^{3}$, Valier Galy ${ }^{4}$, Jérôme Gaillardet ${ }^{1,2}$, Christian France-

4 Lanord $^{5}$, Laurence Maurice ${ }^{6}$, and Patricia Moreira-Turcq ${ }^{7}$

$5{ }^{1}$ Institut de Physique du Globe de Paris, CNRS-UMR 7154, 4, place Jussieu 75252 Paris cedex

6 05, France

$7 \quad{ }^{2}$ Université Paris Diderot, 75205 Paris cedex 13

$8{ }^{3}$ Laboratoire de Géologie, Ecole Normale Supérieure, CNRS-UMR 8538, 24 rue Lhomond,

975231 Paris cedex 05

$10{ }^{4}$ Woods Hole Oceanographic Institution, 360 Woods Hole Rd, Woods Hole, Massachusetts

11 02543, USA

$12{ }^{5}$ Centre de Recherches Pétrographiques et Géochimiques, CNRS-UPR 2300, BP 20, 54501

13 Vandoeuvre-lès-Nancy, France

$14{ }^{6}$ Laboratoire des Mécanismes de Tranfert en Géologie, IRD, 14 avenue Edouard Belin, 31400

15 Toulouse, France

$16{ }^{7}$ IRD-UR 154, 93140 Bondy, France

17 ABSTRACT

18 The two long-term sources of atmospheric carbon are $\mathrm{CO}_{2}$ degassing from metamorphic

19 and volcanic activity, and oxidation of organic carbon (OC) contained in sedimentary rocks, or

20 petrogenic organic carbon $\left(\mathrm{OC}_{\text {petro }}\right)$. The latter flux is still poorly constrained. In this study, we

21 report Particulate Organic Carbon (POC) content and ${ }^{14} \mathrm{C}$-activity measurements in Amazon

22 River sediments, which allow for estimates of the $\mathrm{OC}_{\text {petro }}$ content of these sediments. A large 
Publisher: GSA

Journal: GEOL: Geology

Article ID: G30608

23 decrease of $\mathrm{OC}_{\text {petro }}$ content in riverine sediments is observed from the outlet of the Andes to the

24 mouth of the large tributaries. This loss reveals oxidation of $\mathrm{OC}_{\text {petro }}$ during transfer of sediments

25 in the floodplain, and results in an escape of ca. $0.25 \mathrm{MtC} / \mathrm{yr}$ to the atmosphere, which is on the

26 same order of magnitude as the $\mathrm{CO}_{2}$ consumption by silicate weathering in the same area. Raman

27 microspectroscopy investigations show that graphite is the most stable phase with respect to this

28 oxidation process. These results emphasize the significance of $\mathrm{OC}_{\text {petro }}$ oxidation in large river

29 floodplains in the global C cycle.

30 INTRODUCTION

$31 \quad \mathrm{CO}_{2}$ degassed from Earth's interior is partly scavenged by chemical reactions occurring

32 during weathering of silicate rocks and subsequent carbonate precipitation in the ocean (Garrels

33 et al., 1976). It is also consumed by photosynthesis followed by burial of organic matter in

34 marine sediments (Hayes and Waldbauer, 2006). These two mechanisms have respectively built

35 up the two major carbon reservoirs of Earth's surface: limestones $\left(50 \times 10^{6} \mathrm{GtC}\right)$, and ${ }^{14} \mathrm{C}$-free

36 organic matter disseminated in sedimentary rocks, or petrogenic $\mathrm{OC}\left(\mathrm{OC}_{\mathrm{petro}}, 12.5 \times 10^{6} \mathrm{GtC}\right.$;

37 Berner, 1990). The oxidation of petrogenic OC is a source of $\mathrm{CO}_{2}$ to the atmosphere (Berner,

38 2004). However, quantifying the modern rates of $\mathrm{OC}_{\text {petro }}$ oxidation remains a challenge for

39 understanding and modeling the geological carbon and oxygen cycles. Although a few studies

40 based on soil profiles have attempted to determine rates of $\mathrm{OC}_{\text {petro }}$ oxidation (e.g., Keller and

41 Bacon ; 1998, Petsch et al., 2000), budgets of fossil organic carbon oxidation at river catchment

42 scale have not received much attention (e.g., Galy et al., 2008b ; Hilton et al., 2008).

43 The dissolved and particulate load transported by rivers derive from chemical weathering

44 of rocks and physical erosion of soils and rocks. This includes organic material, which consists

45 in a mixture of recent biospheric carbon $\left(\mathrm{OC}_{\text {recent }}\right)$, and $\mathrm{OC}_{\text {petro }}$ (Blair et al., 2004 ; Komada et al., 
Publisher: GSA

Journal: GEOL: Geology

Article ID: G30608

462004 ; Leithold et al., 2006). The oxidation of OC transported in rivers is thought to mostly

47 affect $\mathrm{OC}_{\text {recent }}$ and to have no effect on the geological budget of atmospheric $\mathrm{CO}_{2}$. In their study

48 on the Amazon river, Hedges et al. (1986) showed that the organic material transported by the

49 Amazon river mostly consists in $\mathrm{OC}_{\text {recent }}$ derived from the highly productive lowland ecosystems.

50 During fluvial transport, the oxidation of this dissolved and particulate organic matter results in

51 the escape of ca. $500 \mathrm{MtC} / \mathrm{yr}$ to the atmosphere (Richey et al., 2002). Most of this oxidation

52 derives from $\mathrm{OC}_{\text {recent }}$ (Mayorga et al., 2005) and has therefore no impact on the long-term

53 regulation of atmospheric $\mathrm{CO}_{2}$. However, a significant fraction of particulate organic matter can

54 be of petrogenic origin. Distinguishing between $\mathrm{OC}_{\text {petro }}$ and $\mathrm{OC}_{\text {recent }}$ in rivers is thus of prime

55 importance because only the oxidation of $\mathrm{OC}_{\text {petro }}$ represents an input of $\mathrm{C}$ to the active reservoirs 56 at Earth's surface.

57 In this study, we report POC (Particulate Organic Carbon) and ${ }^{14} \mathrm{C}$ activity measurements

58 in river sediments collected throughout the Amazon River system. Sediments were collected

59 along river depth-profiles in order to capture the whole range of granulometric spectrum of

60 erosion products. Concentrations of $\mathrm{OC}_{\text {petro }}$ were measured in these sediments, and coupled with

61 structural characterization of $\mathrm{OC}_{\text {petro }}$ by Raman microspectroscopy. This allows us to estimate the

62 first order of carbon input to the atmosphere by $\mathrm{OC}_{\text {petro }}$ oxidation during transfer of sediments in

63 the floodplains of the Amazon Basin, and gives a lower bound on the estimate of $\mathrm{CO}_{2}$ release to

64 the atmosphere by the oxidation of $\mathrm{OC}_{\text {petro }}$ in the Amazon Basin.

65 SETTING, SAMPLING AND ANALYTICAL METHODS

66 The Amazon is the world largest river in terms of drainage area and water discharge to

67 the ocean (Meybeck and Ragu, 1997). Isotopic studies (Allègre et al., 1996) have clearly shown

68 that most of the Amazon River sediments are derived from the Andes. There, Amazon tributaries 
Publisher: GSA

Journal: GEOL: Geology

Article ID: G30608

69 drain extensive outcrops of easily erodible sedimentary and meta-sedimentary rocks, such as

70 black shales in the Bolivian Andes.

71 We sampled the two main tributaries of the Amazon, the Solimões and the Madeira

72 rivers, at their mouth, as well as the Amazon mainstream at Obidos, in June 2005 and March

732006 (Fig. 1). The Beni River, which supplies most of the sediments to the Madeira River, has

74 been sampled at the outlet of the Andes, near Rurrenabaque, where it enters the Madeira

75 floodplain, in February 2001. At each location, river water was sampled at various river depths

76 along vertical profiles, from channel surface to bottom, and filtered at $0.22 \mu \mathrm{m}$ porosity; bed

77 sediments were also dredged. Within the channel of large rivers, granulometric sorting induces

78 important variations of chemical composition of river sediments from the surface to the bottom

79 (Galy et al., 2008a). The sampling technique used here allows us to characterize the whole range

80 of erosion products in terms of grain size distribution and mineralogy.

POC content was determined using a modified Eurovector EuroEA3028-HT elemental

82 analyzer coupled to a GV Instruments IsoPrime continuous-flow isotope mass spectrometer at

83 the CRPG, Vandoeuvre-lès-Nancy, France (Galy et al., 2007). ${ }^{14} \mathrm{C}$ activity was determined by

84 Accelerator Mass Spectrometry at LMC14 National Facility, Saclay, France, after off-line

85 organic matter combustion and $\mathrm{CO}_{2}$ cryogenic purification. Samples were decarbonated before

86 combustion (Galy et al., 2007). ${ }^{14} \mathrm{C}$ values are given after correction for ${ }^{13} \mathrm{C}$ fractionation

87 (normalization to a $\delta^{13} \mathrm{C}$ of $-25 \%$ ), and expressed as pMC (percentage of Modern Carbon)

88 comparatively to $95 \%$ of the ${ }^{14} \mathrm{C}$ activity of the oxalic acid standard OXI. Petrogenic carbon was

89 characterized by Raman microspectroscopy using a Renishaw InVia Raman micro-spectrometer

90 at the Laboratoire de Géologie, Ecole Normale Supérieure, Paris, France (Bernard et al., 2008).

91 Raman spectra were obtained directly on raw sediments, and on thin sections for bedrocks. 
Publisher: GSA

Journal: GEOL: Geology

Article ID: G30608

92 RESULTS: ${ }^{14} \mathrm{C}$ AGE OF OC recent $_{\text {AND OC }}$ petro CONTENT

93 In depth-profile sediments, ${ }^{14} \mathrm{C}$ content shows a wide range of variation, between 37.5

94 and $86.2 \%$ pMC (Tab. 1). A first-order positive relation between pMC and POC is observed, the

95 coarser bed sediments being the most depleted in both OC and ${ }^{14} \mathrm{C}$.

96 In river sediments, $\mathrm{OC}$ can be interpreted as a binary mixture of $\mathrm{OC}_{\text {petro }}$ and $\mathrm{OC}_{\text {recent }}$ with

97 distinct ${ }^{14} \mathrm{C}$ content (e.g., Blair et al., 2004). Following the approach of Galy et al. (2008b) we

98 plot our results in a diagram of POC * pMC (or Modern C) as a function of POC (Fig. 2). Depth-

99 profiles from different sampling locations define linear trends, at 95\% confidence level,

100 regardless the sampling period. These correlation indicate that samples from a given depth-

101 profile have rather constant absolute $\mathrm{OC}_{\text {petro }}$ concentration and ${ }^{14} \mathrm{C}$ activity of the $\mathrm{OC}_{\text {recent }}$

102 component (see appendix for details). The values of $\mathrm{OC}_{\text {petro }}$ content in the samples and ${ }^{14} \mathrm{C}$-age

103 of the $\mathrm{OC}_{\text {recent }}$ pool can be both determined from the slope and intercept of each line (Tab. 1).

104 Similar observations were made on the Ganga-Brahmaputra system (Galy et al., 2008b).

105 The highest $\mathrm{OC}_{\text {petro }}$ content, $0.26 \%( \pm 0.11 \%, 2$ sigma uncertainty $)$, is obtained for the

106 Beni at Rurrenabaque. There, $\mathrm{OC}_{\text {petro }}$ makes up to $50 \%$ of the POC, and likely originates from

107 the large outcrops of black shales drained by this river. Lowland sampling locations (Solimões,

108 Madeira and Amazon) all display lower $\mathrm{OC}_{\text {petro }}$ content, between $0.02 \%$ and $0.06 \%$, (or even

109 lower, regarding the uncertainties reported in Tab. 1). Thus, there is a large apparent decrease in

$110 \mathrm{OC}_{\text {petro }}$ concentration between the entry and the outlet of the Madeira floodplain.

111 Since the Beni contributes to ca. $40 \%$ of the Madeira sedimentary budget (Guyot et al.,

112 1996), potential addition of supposedly $\mathrm{OC}_{\mathrm{petro}}$-free sedimentary material by other tributaries of

113 the Madeira River could only lead to an $\mathrm{OC}_{\text {petro }}$ content decrease by a factor of slightly more than 
Publisher: GSA

Journal: GEOL: Geology

Article ID: G30608

114 two. Hence, the apparent 10 -fold decrease in $\mathrm{OC}_{\text {petro }}$ content could mainly be due either to a

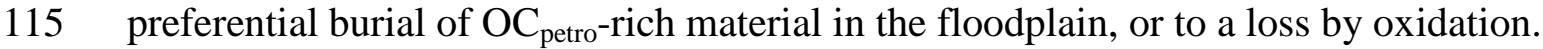

116 Burial of sedimentary material occurs in the Amazon basin between the Andean source of

117 sediments and the Amazon mouth, in particular between Rurrenabaque and the mouth of the

118 Madeira (Guyot et al., 1996). If sediment storage is the cause of the observed decrease of $\mathrm{OC}_{\text {petro }}$

119 concentration reported here, it would imply the preferential sedimentation of an $\mathrm{OC}_{\text {petro }}$ enriched

120 component. As stated above, sampling along depth-profiles allows to take into account the whole

121 range of riverine particulate matter in size distribution and mineralogy. Our results (Fig. 2) show

122 that absolute $\mathrm{OC}_{\text {petro }}$ content is the same along all depth-profiles, despite expected variations in

123 particle size distribution with depth (Curtis et al., 1979). Selective burial of a given size fraction

124 should therefore not affect $\mathrm{OC}_{\text {petro }}$ concentration of suspended sediments. This observation

125 strongly suggests that the decrease of $\mathrm{OC}_{\text {petro }}$ concentration along the course of the Madeira is

126 due to $\mathrm{OC}_{\text {petro }}$ oxidation.

127 ESTIMATE OF THE MAGNITUDE OF THE $\mathrm{CO}_{2}$ SOURCE

128 Given the important amount of sediments transported in the Madeira floodplain (Guyot et

129 al., 1996), the oxidation flux resulting from the large decrease in $\mathrm{OC}_{\text {petro }}$ content during the

130 transfer of sediments in the floodplain should be significant. A first-order oxidation flux of

$131 \mathrm{OC}_{\text {petro }}$ can be estimated using previous works on sedimentary budgets in the Madeira River

132 Basin. Among the $212 \mathrm{Mt} / \mathrm{yr}$ of sediments delivered by the Beni River to the plain, ca. one half is

133 buried in the foreland basin (Guyot et al., 1996). The amount of Beni sediments actually

134 transiting through the plain is thus on the order of $100 \mathrm{Mt} / \mathrm{yr}$. Hence, given the $\mathrm{OC}_{\text {petro }}$

135 concentration reported in this study, $100 \mathrm{Mt} / \mathrm{yr}$ of sediments represent a $\mathrm{OC}_{\text {petro }}$ flux of 0.26

$136 \mathrm{MtC} / \mathrm{yr}$ supplied to the plain and not buried. At the outlet, $100 \mathrm{Mt} / \mathrm{yr}$ of sediments represent a 
Publisher: GSA

Journal: GEOL: Geology

Article ID: G30608

$137 \mathrm{OC}_{\text {petro }}$ flux of $0.02 \mathrm{MtC} / \mathrm{yr}$ that exits the plain. The difference of ca. $0.25 \mathrm{MtC} / \mathrm{yr}$ is thus the

138 oxidation flux of $\mathrm{OC}_{\text {petro }}$ in the Madeira floodplain. This is a first order estimate but also a lower

139 bound of the $\mathrm{OC}_{\text {petro }}$ oxidation flux of the Madeira basin as we assumed that no $\mathrm{OC}_{\text {petro }}$ is

140 delivered to the Madeira floodplain by its two other main tributaries. In addition, this estimate

141 does not take into account the oxidation of $\mathrm{OC}_{\text {petro }}$ upstream Rurrenabaque and in Andean soils

142 which we are not able to address here. Moreover, we assume that no oxidation affects the

143 sediments buried in the foreland basin. The flux of $0.25 \mathrm{MtC} / \mathrm{y}$ is thus a minimum bound of the

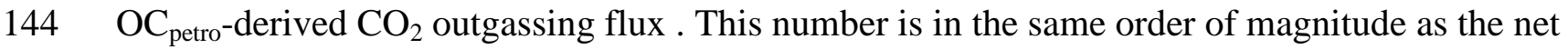

$145 \mathrm{CO}_{2}$ sequestration flux in this basin associated to silicate weathering $(0.8 \mathrm{MtC} / \mathrm{yr}$; Gaillardet et

146 al., 1997).

147 OC $_{\text {petro }}$ STRUCTURAL CHARACTERIZATION

$148 \quad \mathrm{OC}_{\text {petro }}$ is derived from organic carbon initially trapped in sediments and has been

149 structurally and chemically transformed during diagenesis and metamorphism. Structural

150 characterization of $\mathrm{OC}_{\text {petro }}$ by Raman microspectroscopy has been performed both in riverine

151 sediments and bedrock samples. Because volcanic rocks of the high cordillera may not contain

152 any significant amount of solid $\mathrm{OC}$, the main sources of $\mathrm{OC}_{\text {petro }}$ are most likely the sediments,

153 mainly black shales, drained by the Rio Beni. Three samples representative of the main bedrock

154 lithologies from the Tipuani, Mapiri and Coroico basin have been investigated (Fig. 1). They

155 contain two main $\mathrm{OC}_{\text {petro }}$ fractions (Fig. 3): one is rather disordered, exhibiting Raman spectra

156 typical of greenschist facies (Beyssac et al., 2002), in agreement with the thermal history of these

157 rocks. The second is highly graphitic and supposedly represents a detrital pool. Both fractions are

158 found in all riverine sediments either as isolated particles or as inclusions or aggregates within

159 minerals (mostly quartz, phyllosilicates or plagioclases, Fig. 3). As shown in Fig. 3, the graphitic 
Publisher: GSA

Journal: GEOL: Geology

Article ID: G30608

160 phases become dominant in samples of downstream sediment (Rio Beni and then Rio Madeira),

161 while the disordered fraction progressively disappears. Graphite thus appears to be the most

162 stable phase with respect to the oxidation process.

163 DISCUSSION AND CONCLUSION

This study thus shows that the oxidation of $\mathrm{OC}_{\text {petro }}$ during fluvial transport is a significant

165 flux for the long-term atmospheric $\mathrm{CO}_{2}$ budget. Fluvial oxidation of $\mathrm{OC}_{\text {petro }}$ may counteract the

166 consumption flux of $\mathrm{CO}_{2}$ by silicate weathering, which is conventionally thought to be the only

167 significant process, with organic carbon sequestration, to control atmospheric $\mathrm{CO}_{2}$ at geological

168 timescales (Berner, 2004; Wallmann, 2001). The degradation of physically mobilized ancient

169 organic matter in large fluvial systems is most probably dependent on a number of factors such

170 as residence time of particles in floodplains (Blair et al., 2003), or on climatic conditions. This

171 important oxidation flux found here is probably favored by the warm and oxidative conditions

172 that prevail in the soils of Amazonian floodplains. Whether this oxidation of $\mathrm{OC}_{\text {petro }}$ occurs via

173 biotic (Petsch et al., 2001) or abiotic (Chang and Berner, 1999) pathways, is beyond the scope of

174 the paper but would need further investigations.

175 Galy et al. (2008b) showed that $30 \%-50 \%$ of the $\mathrm{OC}_{\text {petro }}$ present in the Himalayan source

176 rocks were preserved and are still present in the marine sediments of the Bengal Fan. Our

177 estimate of the $\mathrm{OC}_{\text {petro }}$ preservation in the Madeira floodplain, 15\%, is an upper bound of the

178 extent of $\mathrm{OC}_{\text {petro }}$ preservation in the Madeira basin, as it does not take into account the oxidation

179 taking place in Andean soils, downstream the sampling locations, or even in the ocean, before or

180 after deposition. The Amazon basin is hence a better incinerator of $\mathrm{OC}_{\text {petro }}$ than the Himalayan

181 system. This is likely due to differences in the sources of $\mathrm{OC}_{\text {petro }}$. Low-grade metamorphic rocks

182 with disordered OC are common in the Andes, while high-grade metamorphic rocks generating 
Publisher: GSA

Journal: GEOL: Geology

Article ID: G30608

183 highly graphitic OC are widespread in the Himalaya (Beyssac et al., 2004). Disordered OC is

184 more prone to oxidation than graphite because of its chemistry (aromatic skeleton with

185 radicalization) and structure, as micro- and nano-porosity enhance oxidation rates.

186 Over geological timescale, geodynamic (metamorphic grade, erosion intensity...) settings

187 probably control the extent of preservation of $\mathrm{OC}_{\text {petro }}$ during the erosion-transport-sedimentation

188 cycle. Over shorter timescale (tens to hundreds kyrs), and for a given geodynamic context,

189 climate is likely to control the oxidation or preservation of $\mathrm{OC}_{\text {petro }}$, through erosion, temperature,

190 and probably the nature of microbial communities (and their metabolic activity) present in the

191 floodplain.

192 We speculate that, in response to an atmospheric $\mathrm{CO}_{2}$ rise, increased global temperature

193 would probably enhance oxidation of petrogenic OC in large river floodplains and associated

$194 \mathrm{CO}_{2}$ outgassing. This mechanism possibly constitutes a new positive feedback in the

195 long-term carbon cycle.

\section{ACKNOWLEDGMENTS}

This study was funded by CNRS-INSU program Reliefs de la Terre, and realized in

the frame of the HyBAm project (cooperation agreement with CNPq $n^{\circ} 492685 / 2004-5$ ). We sincerely ackowledge the following Brazilian Institutions and Universities: ANA, UnB, UFF,

CPRM. We thank C. Guilmette for technical assistance in the stable isotopes laboratory and

201 R. Hilton for improving the quality of the text. This is IPGP contribution $\mathrm{N}^{\circ} 2564$.

\section{APPENDIX: OC petro $_{\text {AND }}{ }^{14}$ C AGE OF OC recent $_{\text {CALCULATION }}$}

203 We use a method described in Galy et al., 2008b. Briefly, we describe the OC pool as a binary

204 mixture of $\mathrm{OC}_{\text {petro, }}$, derived from the rocks, and $\mathrm{OC}_{\text {recent }}$ derived from the biosphere (vegetation,

205 soils and autotrophic production in the river). These two component have distinct ${ }^{14} \mathrm{C}$ activity, 
Publisher: GSA

Journal: GEOL: Geology

Article ID: G30608

$206 \mathrm{OC}_{\mathrm{petro}}$ being ${ }^{14} \mathrm{C}$-free $(\mathrm{pMC}$ petro $=0)$. For each sample, the absolute content of Modern C $(\mathrm{POC} \mathrm{x}$

207 pMC - "Modern" refering here to a present ${ }^{14} \mathrm{C}$ standard) can thus be written as:

$208 \%$ Modern $\mathrm{C}=\mathrm{POC} \times \mathrm{pMC}_{\text {recent }}-\% \mathrm{OC}_{\text {petro }} \times \mathrm{pMC}_{\text {recent }}$,

209 where $\mathrm{pMC}_{\text {recent }}$ is the ${ }^{14} \mathrm{C}$ activity of $\mathrm{OC}_{\text {recent }}$ and $\% \mathrm{OC}_{\text {petro }}$ is the absolute content of $\mathrm{OC}_{\text {petro. In a }}$

$210 \%$ Modern $\mathrm{C}$ vs. POC plot, samples having the same $\mathrm{pMC}_{\text {recent }}$ and the same $\% \mathrm{OC}_{\text {petro }}$ define a

211 single straight line. The $\mathrm{pMC}_{\text {recent }}$ is given by the slope of the line and allows the calculation of

212 the age of the recent component. Moreover, the absolute content of $\mathrm{OC}_{\text {petro }}$ is given by the

213 opposite of the intercept/slope ratio.

214 Despite the auto-correlated nature of the two plotted variables, and as shown in Tab. 1, the

215 relationships we obtain are more significantly correlated than in the case of randomly distributed

216 POC and pMC (either assuming an uniform or normal distribution, within boundaries defined by

217 the ranges covered by the values measured in our samples).

218 Uncertainties on the determined slope and intercept (and thus on $\% \mathrm{OC}_{\text {petro }}$ and $\mathrm{pMC}_{\text {recent }}$ ) are

219 yielded by a full inversion method (Tarantola and Valette, 1982). Relatively low uncertainties on

$220 \mathrm{pMC}_{\text {recent }}$ (i.e. on the slope) stem from the good alignment of data points.

221 REFERENCES CITED

222 Allègre, C.J., Dupré, B., Négrel, P., and Gaillardet, J., 1996, Sr-Nd-Pb isotope systematics in

223 Amazon and Congo River systems: constraints about erosion processes: Chemical Geology,

224 v. 131, p. 93-112, doi: 10.1016/0009-2541(96)00028-9.

225 Bernard, S., Beyssac, O., and Benzerara, K., 2008, Raman mapping using advanced line-

226 scanning systems: geological applications: Applied Spectroscopy, v. 62, p. 1180-1188.

227 Berner, R.A., 2004, The Phanerozoic carbon cycle, Oxford University Press, 150 pp. 
Publisher: GSA

Journal: GEOL: Geology

Article ID: G30608

228 Berner, R.A., 1990, Atmospheric carbon dioxide levels over Phanerozoic time: Science, v. 249,

229 p. 1382-1386, doi: 10.1126/science.249.4975.1382.

230 Beyssac, O., Goffé, B., Chopin, C., and Rouzaud, J.-N., 2002, Raman spectra of carbonaceous

231 material in metasediments: a new geothermometer: Journal of Metamorphic Geology, v. 20,

232 no. 9, p. 859-871, doi: 10.1046/j.1525-1314.2002.00408.x.

233 Beyssac, O., Bollinger, L., Avouac, J.-P., and Goff, È., B., 2004, Thermal metamorphism in the

234 Lesser Himalaya of Nepal determined from Raman spectroscopy of carbonaceous material:

235 Earth and Planetary Science Letters, v. 225, p. 233-241.

236 Blair, N.E., Leithold, E.L., Ford, S.T., Peeler, K.A., Holmes, J.C., and Perkey, D.W., 2003, The

237 persistence of memory: the fate of ancient sedimentary organic carbon in a modern

238 sedimentary system: Geochimica et Cosmochimica Acta, v. 67, no. 1, p. 63-73, doi:

$239 \quad$ 10.1016/S0016-7037(02)01043-8.

240 Blair, N.E., Leithold, E.L., and Aller, R.C., 2004, From bedrock to burial: the evolution of

241 particulate organic carbon across coupled watershed-continental margin systems: Marine

242 Chemistry, v. 92, p. 141-156, doi: 10.1016/j.marchem.2004.06.023.

243 Chang, S., and Berner, R.A., 1999, Coal weathering and the geochemical carbon cycle:

244 Geochimica et Cosmochimica Acta, v. 63, no. 19/20, p. 3301-3310, doi: 10.1016/S0016-

$245 \quad 7037(99) 00252-5$.

246 Curtis, W.F., Meade, R.H., Nordin, C.F., Price, N.B., and Sholkovitz, E.R., 1979, Non-uniform

247 vertical distribution of fine sediment in the Amazon River: Nature, v. 280, p. 381-383, doi:

$248 \quad 10.1038 / 280381 \mathrm{a} 0$. 
Publisher: GSA

Journal: GEOL: Geology

Article ID: G30608

249 Gaillardet, J., Dupré, B., Allègre, C.J., and Négrel, P., 1997, Chemical and physical denudation

250 in the Amazon River Basin: Chemical Geology, v. 142, p. 141-173, doi: 10.1016/S0009-

251 2541(97)00074-0.

252 Galy, V., Bouchez, J., and France-Lanord, C., 2007, Determination of Total Organic Carbon content and ${ }^{13} \mathrm{C}$ in carbonate-rich detrital sediments: Geostandards and Geoanalytical Research, v. 31, no. 3, p. 199-207, doi: 10.1111/j.1751-908X.2007.00864.x.

255 Galy, V., France-Lanord, C., and Lartiges, B., 2008a, Loading and fate of particulate organic 256 carbon from the Himalaya to the Ganga-Brahmaputra delta: Geochimica et Cosmochimica Acta, v. 72, no. 7, p. 1767-1787, doi: 10.1016/j.gca.2008.01.027.

Galy, V., Beyssac, O., France-Lanord, C., and Eglinton, T.I., 2008b, Recycling of graphite during Himalayan erosion: a geological stabilization of carbon in the crust: Science, v. 322,

Garrels, R.M., Lerman, A., and Mackenzie, F.T., 1976, Controls of atmospheric $\mathrm{O}_{2}$ and $\mathrm{CO}_{2}-$ past, present and future: American Scientist, v. 63, p. 306-315.

Guyot, J.-L., Filizola, N., Quintanilla, J., and Cortez, J., 1996, Dissolved solids and suspended sediment yields in the Rio Madeira basin, from the Bolivian Andes to the Amazon: IAHS Publication, v. 236, p. 55-63.

Hayes, J.M., and Waldbauer, J.R., 2006, The carbon cycle and associated redox processes through time: Philosophical Transactions of the Royal Society, v. 361, no. 1470, p. 931-950,

269 Hedges, J.I., Quay, P.D., Grootes, P.M., Richey, J.E., Devol, A.H., Farwell, G.W., Schmidt, 270 F.W., and Salati, E., 1986, Carbon-14 in the Amazon River System: Science, v. 231, 271 p. 1129-1131, doi: 10.1126/science.231.4742.1129. 
Publisher: GSA

Journal: GEOL: Geology

Article ID: G30608

272 Hilton, R.H., Galy, A., Hovius, N., Chen, M.-C., Horng, M.-J., and Chen, H., 2008, Tropical-

273 cyclone-driven erosion of the terrestrial biosphere from mountains: Nature Geosciences,

274 v. 1, p. 759-762, doi: 10.1038/ngeo333.

275 Keller, C.K., and Bacon, D.H., 1998, Soil respiration and georespiration distinguished by

276 transport analyses of vadose $\mathrm{CO}_{2},{ }^{13} \mathrm{CO}_{2}$ and ${ }^{14} \mathrm{CO}_{2}$ : Global Biogeochemical Cycles, v. 12, no. 2, p. 361-372, doi: 10.1029/98GB00742.

278 Komada, T., Druffel, E.R.M., and Trumbore, S.E., 2004, Oceanic export of relict carbon by

279 small mountainous rivers: Geophysical Research Letters, v. 31, p. L07504, doi:

$280 \quad 10.1029 / 2004 G L 019512$.

281 Leithold, E.L., Bair, N.E., and Perkey, D.W., 2006, Geomorphic controls on the age of

282 particulate organic carbon from small mountainous and upland rivers: Global

283 Biogeochemical Cycles, v. 20, p. GB3022, doi: 10.1029/2005GB002677.

284 Mayorga, E., Aufdenkampe, A.K., Masiello, C.A., Krusche, A.V., Hedges, J.I., Quay, P.D.,

285 Richey, J.E., and Brown, T.A., 2005, Young organic matter as a source of carbon dioxide

286 outgassing from Amazonian rivers: Nature, v. 436, no. 28, p. 538-541, doi:

$287 \quad 10.1038 /$ nature03880.

288 Meybeck, M., and Ragu, A., 1997, River discharges to the oceans: an assessment of suspended 289 solids, major ions and nutrients, UNEP, WHO.

290 Petsch, S.T., Berner, R.A., and Eglinton, T.I., 2000, A field study of chemical weathering of

291 ancient sedimentary organic matter: Organic Geochemistry, v. 31, p. 475-487, doi:

292 10.1016/S0146-6380(00)00014-0. 
Publisher: GSA

Journal: GEOL: Geology

Article ID: G30608

293 Petsch, S.T., Eglinton, T.I., and Edwards, K.J., 2001, ${ }^{14}$ C-dead living biomass: evidence for

294 microbial assimilation of ancient organic carbon during shale weathering: Science, v. 292,

295 p. 1127-1131, doi: $10.1126 /$ science. 1058332.

296 Richey, J.E., Melack, J.M., Aufdenkampe, A.K., Ballester, V.M., and Hess, L.L., 2002,

297 Outgassing from Amazonian rivers and wetlands as a large tropical source of atmospheric

$298 \quad \mathrm{CO}_{2}$ : Nature, v. 416, p. 617-620, doi: $10.1038 / 416617 \mathrm{a}$.

299 Tarantola, A., and Valette, B., 1982, Generalized nonlinear inverse problems solved using the

300 least squares criterion: Reviews of Geophysics and Space Physics, v. 20, no. 2, p. 219-232,

301 doi: 10.1029/RG020i002p00219.

302 Wallmann, K., 2001, Controls on the Cretaceous and Cenozoic evolution of seawater composition, atmospheric $\mathrm{CO}_{2}$ and climate: Geochimica et Cosmochimica Acta, v. 65,

\section{FIGURE CAPTIONS}

306 Figure 1. Map of the Amazon basin and sampling sites.

307 Figure 2. Modern C content (POC*pMC, expressed in weight $\%$ of the whole sample) vs. POC

308 for sediments collected along a depth profile in different rivers of the Amazon basin. The linear

309 regression solution for each sampling location is also shown. Open symbols stand for bedload

310 sediments, closed symbols for suspended load sediments. Samples are plotted regardless of their

311 position in the hydrological cycle.

312 Figure 3. Representative Raman spectra of riverine and bedrock material, with the location of the

313 main graphite $\mathrm{G}$ band, and the D1, D2 and D3 defect bands. Minerals associated with C are also

314 indicated. Fossil organic matter was found as free particles, inclusions in minerals such as quartz

315 or rutiles, or aggregates with phyllosilicates. Free particles were as large as $20 \mu \mathrm{m}$ in diameter. 
Publisher: GSA

Journal: GEOL: Geology

Article ID: G30608

316

TABLE 1. SAMPLE LIST AND RESULTS:

ANALYTICAL ABSOLUTE UNCERTAINTIES (2 $\sigma)$ ARE $0.5 \mathrm{M}$

\begin{tabular}{lccccccc}
\multicolumn{6}{c}{ FOR SAMPLING DEPTH, 0.3\% FOR PMC AND 0.02\% FOR POC } \\
\hline Sample & River & $\begin{array}{c}\text { Water } \\
\text { stage }\end{array}$ & $\begin{array}{c}\text { Depth } \\
(\mathrm{m})\end{array}$ & $\begin{array}{c}\text { pMC } \\
(\%)\end{array}$ & $\begin{array}{c}\text { POC } \\
(\%)\end{array}$ & $\begin{array}{c}\mathrm{pMC}_{\text {recent }} \\
(\%)\end{array}$ & $\begin{array}{c}\mathrm{OC}_{\text {petro }} \\
(\%)\end{array}$ \\
\hline AM-05-35 & Amazon & Falling & 58 & 78.6 & 0.65 & 84 & 0.06 \\
AM-05-37 & & Falling & 30 & 78.4 & 0.92 & \pm 0.04 & \pm 0.05 \\
AM-05-39 & & Falling & 2 & 81.4 & 1.22 & $\left(\mathrm{r}^{2}=0.995\right)$ & \\
AM-06-64 & & Rising & 20 & 76.9 & 0.93 & & \\
AM-06-66 & & Rising & Bedload & 77.3 & 0.65 & & \\
AM-05-04 & Solimões & High & 28 & 86.2 & 0.79 & 87 & 0.03 \\
AM-05-08 & & High & 2 & 83.3 & 1.13 & \pm 0.03 & \pm 0.02 \\
AM-05-10 & & High & Bedload & 37.5 & 0.06 & $\left(r^{2}=0.998\right)$ & \\
AM-06-10 & & Rising & 22 & 82.7 & 0.95 & & \\
AM-06-36 & Madeira & High & 15 & 70.6 & 0.62 & 71 & 0.02 \\
AM-06-38 & & High & 0 & 68.3 & 0.65 & \pm 0.04 & \pm 0.03 \\
AM-06-44 & & High & Bedload & 45.5 & 0.05 & $\left(r^{2}=0.999\right)$ & \\
AM-01-14-a & Beni & High & 1 & 44.1 & 0.51 & 96 & 0.26 \\
AM-01-14-b & & High & 3 & 55.1 & 0.61 & \pm 0.13 & \pm 0.11 \\
AM-01-14-c & & High & 5 & 42.0 & 0.45 & $\left(r^{2}=0.986\right)$ & \\
AM-01-14-d & & High & 7 & 41.0 & 0.47 & & \\
\hline
\end{tabular}

317

Page 15 of 15 